\title{
Kaempferia nigrifolia (Zingiberaceae), a new species from Central Thailand
}

\author{
Boonma T. ${ }^{1}$, Saensouk S. ${ }^{2 \star} \&$ P. Saensouk ${ }^{3}$ \\ ${ }^{1}$ Brio Garden, 53 M.5 Ban Mai Village, Phikun Ok, Ban Na District, Nakhon Nayok - 261 10, Thailand \\ 2Plant and Invertebrate Taxonomy and its Applications Unit Group, Walai Rukhavej Botanical Research Institute, \\ Mahasarakham University, Kantarawichai District, Maha Sarakham - 44150, Thailand \\ ${ }^{3}$ Plant and Invertebrate Taxonomy and its Applications Unit Group, Department of Biology, Faculty of Science, \\ Mahasarakham University, Maha Sarakham - 441 50, Thailand \\ *E-mail: surapon.s@msu.ac.th
}

\begin{abstract}
Kaempferia nigrifolia Boonma \& Saensouk, a new species of Zingiberaceae from Central Thailand, is described and illustrated along with photographs, notes on its distribution and habitat. An identification key to the species of Kaempferia in Thailand is also presented.
\end{abstract}

Keywords: Kaempferia, New species, Taxonomy, Thailand, Zingiberaceae.

\section{Introduction}

Kaempferia L. (Zingiberaceae) commemorates the German physician and traveler Engelbert Kaempfer (1651-1716), the first westerner who collected plant specimens in Thailand (Larsen \& Larsen, 2006). Based on the position of the inflorescence, the genus is divided into two subgenera: subgen. Kaempferia (Baker, 1890) and subgen. Protanthium (Horan.) Baker (Insisiengmay et al., 2018). Species in subgen. Kaempferia produce terminal inflorescences while those in subgen. Protanthium produce inflorescences directly from the rhizome (Insisiengmay et al., 2018). Sirirugsa (1992) recognized fifteen species of Kaempferia from Thailand. Subsequently, about forty species were reported by Boonma et al. (2020) and Jenjittikul and Larsen (2020). While investigating the species diversity of Zingiberaceae in Thailand, specimens of an undescribed species of Kaempferia similar to K. pulchra Ridl. was found in Saraburi province, Central Thailand. After

Received: 31.05.2020; Revised \& Accepted: 14.12.2020

Published Online: 31.03 .2021 comparing and examining species with similar characteristics, we found that this specimen did not match any existing taxa, hence it is described and illustrated here as new to science. A key to species of Kaempferia in Thailand is provided for facilitating their identification.

\section{Materials and Methods}

Live specimens of Kaempferia were collected from the field in Wihan Daeng District, Saraburi Province, Central Thailand, between 2018 and 2019 and measurements of the plant parts were taken. The protologues of morphologically similar species (Baker, 1890; Ridley, 1899; Holttum, 1950) and type specimens housed in various herbaria (BK, BKF, KKU, QBG) in Thailand, including digital images available online were compared.

\section{Taxonomic treatment}

Kaempferia nigrifolia Boonma \& Saensouk, sp. nov.

Figs. 1-3

The new species is similar to $K$. pulchra Ridl. but differs in having sessile leaves, shorter $(c .1 \mathrm{~cm}$ long) peduncle, broadly obovate light purple staminodes with white spot at base, longer than labellum, deeply divided light purple labellum with a white spot at the base and obovate lobes, sessile stamens and white triangular anther-crest which is bend to the back and lower than the plane of the petals. Type: THAILAND, Saraburi Province, Wihan Daeng district, 70-185 m, 03.08.2018, T. Boonma 14 (holo KKU!; iso QBG!, BKF!, BK!). 

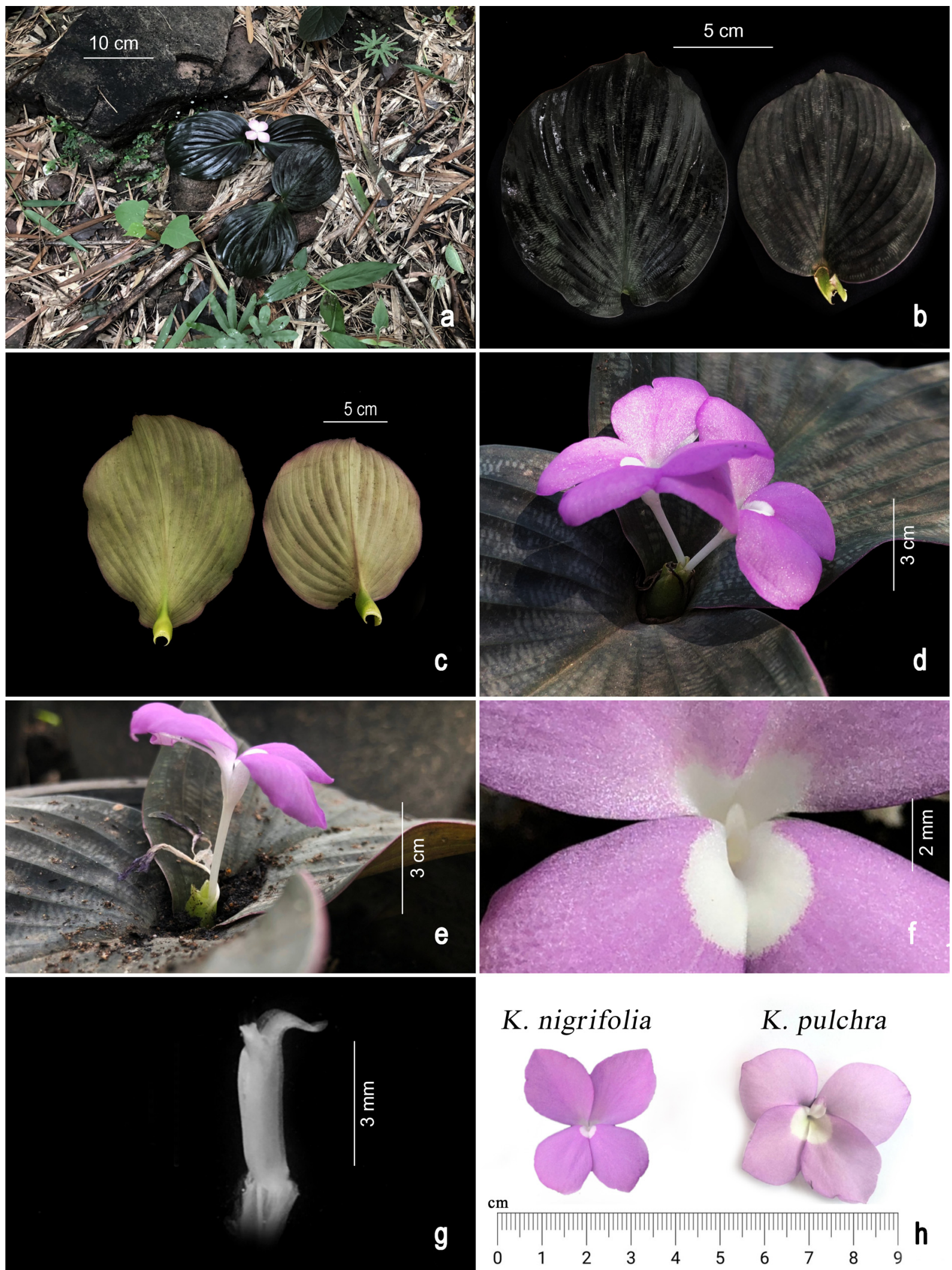

K. nigrifolia

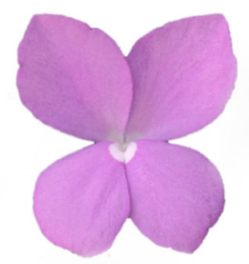

(1)

K. pulchra

Fig. 1. Kaempferia nigrifolia Boonma \& Saensouk: a. Plants in natural habitat; b. Leaf-upper surface; c. Leaf-lower surface; d. Floweroblique top view; e. Flower-side view; f. Flower-top view; g. Anther with crest; h. Comparison of flowers of K. nigrifolia and K. pulchra-top views (a-g from T. Boonma 14; photos by Thawatphong Boonma) 


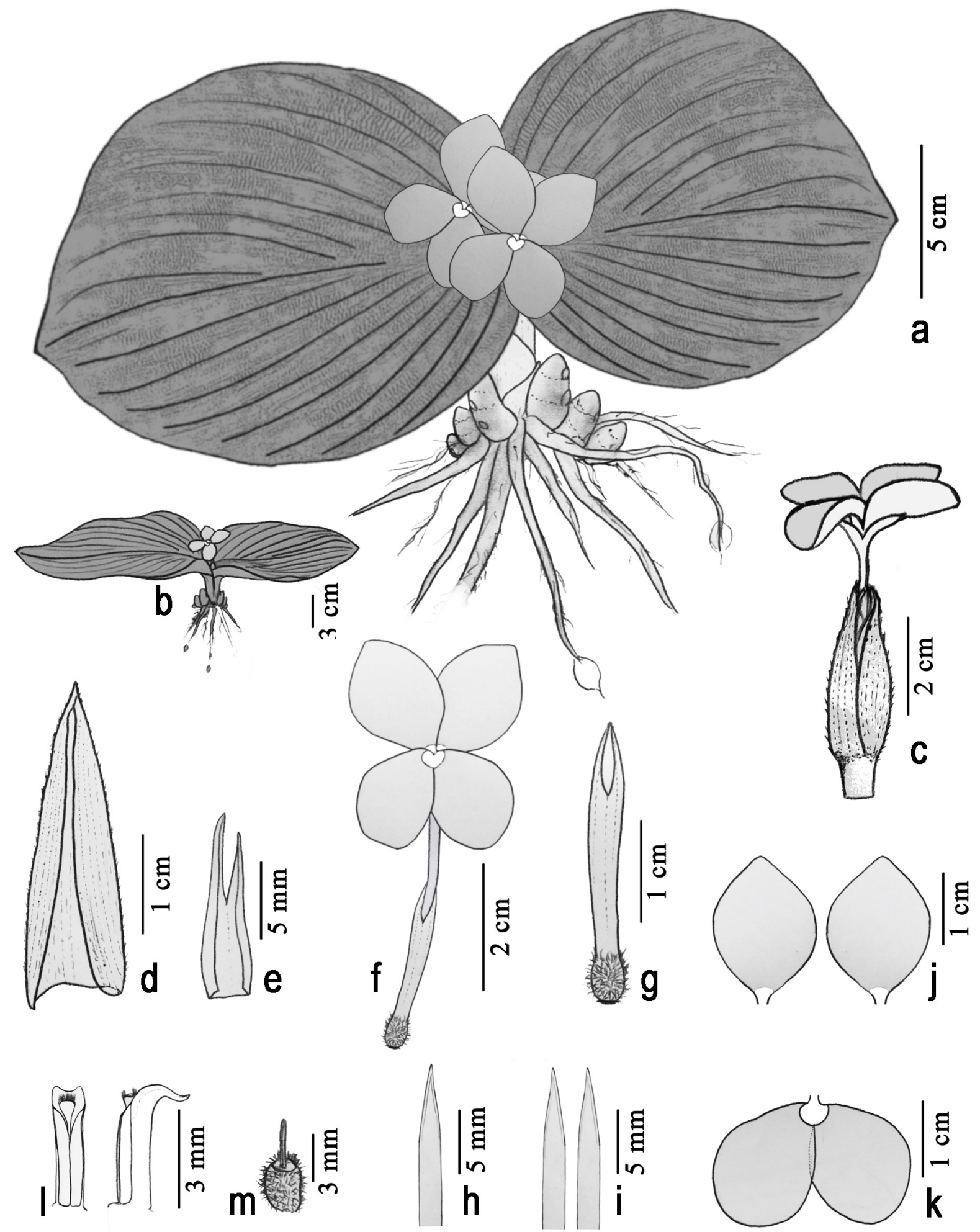

Fig. 2. Kaempferia nigrifolia Boonma \& Saensouk: a. Habit-top view; b. Habit-oblique side view; c. Inflorescence; d. Bract; e. Bracteole; f. Flower with calyx and ovary; g. Calyx and ovary; h. Corolla dorsal lobe; i. Corolla lateral lobes; j. Lateral staminodes; k. Labellum; I. Anther with crest and stigma; m. Ovary with epigynous glands (from T. Boonma 14; drawn by Thawatphong Boonma). 


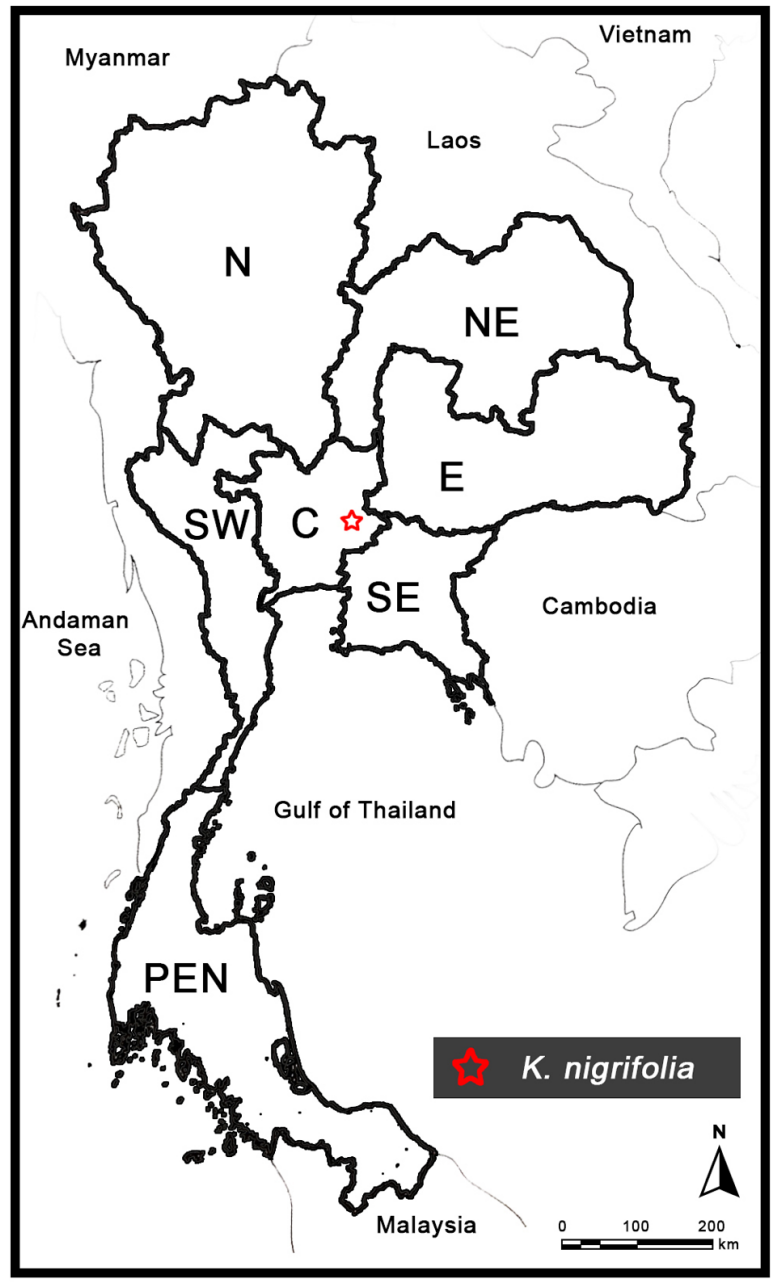

Fig. 3. Map showing the distribution of $K$. nigrifolia Boonma \& Saensouk in Thailand.

Perennial herbs, c. $3 \mathrm{~cm}$ tall. Rhizome vertical, ovoid, brown outside, pale yellow inside, lightly fragrant, c. $2.5 \times 1.5 \mathrm{~cm}$, with several fibrous roots bearing tubers. Cataphylls 2-3, lanceolate, apex acuminate, dark reddish-brown, green at base, 1$3 \mathrm{~cm}$ long, hairy. Leaves 2, sessile, flat or horizontal on the ground; sheaths $2.5-3 \mathrm{~cm}$ long, green or green with reddish-brown, hairy; ligule membranous, $1-3 \times$ c. $10 \mathrm{~mm}$, bi-lobed with rounded apex, sparsely hairy; lamina orbicular to sub-orbicular, 12-16(-18) × 11.5-14(-16) cm, base cuneate or sub-cordate, apex acute, margins entire, widely undulate with dark reddish-brown along the margins, upper surface black or black with light grey markings, sparsely hairy (mostly at the midribbase), obviously embossed veins, lower surface grey-green with reddish-brown, veins hairy. Inflorescence enclosed by two cataphylls; peduncles less than $1.4 \mathrm{~cm}$ long, white with light pale green at tip, glabrous. Bracts lanceolate, 2.8-3.3 × 1.1$1.7 \mathrm{~cm}$, mucronate to acute at apex, green with brownish green at tip and pale green at base, hairy. Bracteoles lanceolate, 11.5-12.3 × c. $4 \mathrm{~mm}$, translucent white, bi-lobed; lobes 5-6 mm, acuminate at apex, sparsely hairy. Flowers 24-27. Calyx tubular, translucent white, c. $2.3 \mathrm{~cm}$ long, with one deep incision c. $6 \mathrm{~mm}$, apex acute, hairy. Corolla tube white, c. $3.5 \mathrm{~cm}$ long; dorsal lobe lanceolate, white, c. $1.5 \times 0.32 \mathrm{~cm}$, apex little hooded, acuminate; lateral lobes lanceolate, white, c. $1.3 \times 0.35 \mathrm{~cm}$, apex little hooded, acuminate, glabrous. Staminodes 2, broadly obovate, obtuse at apex, c. $1.9 \times 1.5 \mathrm{~cm}$, light purple above with white spot at base, white below, glabrous. Labellum light purple above with a white spot at base, white below, deeply divided to the edge of white spot; lobes obovate, c. $1.75 \times 1.4 \mathrm{~cm}$, apex rounded. Stamens sessile, white, glabrous; anthers c. $3.2 \mathrm{~mm}$ long; anther-crest triangular and bend to the back, c. 1.3 $\times 1 \mathrm{~mm}$, lower than the plane of the petals, acuminate at apex, white, glabrous. Ovary spheroid, 3.5-4 × c. $2.5 \mathrm{~mm}$, densely hairy; style filiform, c. 4 cm long, slender, white; stigma obconic, c. $1 \times 0.8$ $\mathrm{mm}$, creamy white, 2-lipped, lips equal, ciliate, cilia c. $0.4 \mathrm{~mm}$ long; epigynous glands 2, c. $3 \mathrm{~mm}$ long, slender, white. Capsules sub-globose to prolate spheroid, c. $1.2 \times 1 \mathrm{~cm}$, densely hairy, light purple with purple veins, brown when old; seeds $c .3 \times 2$ $\mathrm{mm}$, brown with white arils.

Vernacular name: 'Nillakan' in Thai language, refers to its black leaves.

Flowering \& fruiting: Flowering from late May to September and fruiting from August to late October.

Habitat: Occurring at elevations of 70-185 meters above sea level, growing in sandy loam soil, moist and close to the watercourse in a deciduous forest.

Etymology: The specific epithet 'nigrifolia' is derived from two Latin words; 'nigrum' meaning 'black' and 'folia' meaning 'leaves' referring to its black leaves. 
Table. 1 Morphological comparison of K. nigrifolia and K. pulchra

\begin{tabular}{|c|c|c|}
\hline Characters & K. nigrifolia Boonma \& Saensouk & K. pulchra Ridl. \\
\hline Leaves & $\begin{array}{l}\text { Orbicular to sub-orbicular, flat, or horizontal } \\
\text { on the ground, black or black with light grey } \\
\text { markings adaxially and dark reddish-brown } \\
\text { along the margins, sparsely hairy } \\
\text { (mostly at the midrib-base) }\end{array}$ & $\begin{array}{l}\text { Ovate, blunt, spreading out usually flat on the } \\
\text { ground, dark olivaceous black with grey markings } \\
\text { above, glabrous }\end{array}$ \\
\hline Petioles & Absent & c. $7.42 \mathrm{~cm}$ long \\
\hline Peduncle & $\leq 1.4 \mathrm{~cm}$ long,white with light pale green at tip & c. $7.62 \mathrm{~cm}$ long, green \\
\hline Corolla lobes & Lanceolate, apex little hooded, acuminate & Linear, obtuse, reflexed \\
\hline Staminodes & $\begin{array}{l}\text { Broadly obovate, light purple with a white spot } \\
\text { at base, longer than labellum }\end{array}$ & Obovate, mauve, as long as labellum \\
\hline Labellum & $\begin{array}{l}\text { Light purple above with pure white spot at base, } \\
\text { lower surface white; deeply divided to the edge } \\
\text { of white spot; lobes obovate, apex rounded }\end{array}$ & $\begin{array}{l}\text { Mauve with the base pale yellowish white, } \\
\text { deeply bilobed; lobes oblong, apices rounded } \\
\text { to obtuse }\end{array}$ \\
\hline Stamen & Sessile & With very short filament \\
\hline Stigma & Lips equal & Lower lip prolonged \\
\hline Anther crest & $\begin{array}{l}\text { White, triangular and bend to the back, lower } \\
\text { than the plane of the petals, apex acuminate }\end{array}$ & $\begin{array}{l}\text { White with mauve tip, long-linear, apex rounded, } \\
\text { recurved }\end{array}$ \\
\hline
\end{tabular}

Distribution: Hitherto endemic to Central Thailand (Fig. 3).

\section{Key to the species of Kaempferia in Thailand}

1. Inflorescence terminal from pseudostem, appears along with leaves (subgen. Kaempferia)

1. Inflorescence directly from rhizome, appears before the new leave (subgen. Protanthium) .. .26

2. Leaves erect from the ground. 3

2. Leaves horizontal near the ground.... 13

3. Lamina filiform, linear or less than $4 \mathrm{~cm}$ broad 4

3. Lamina lanceolate to orbicular, broader than $4 \mathrm{~cm}$, 8

4. Leaves villous below K. spoliata

4. Leaves glabrous 5

5. Staminodes absent K. sisaketensis

5. Staminodes present.

6. Ligules present; leaves elliptic-linear to linear, $0.5-1 \mathrm{~cm}$ broad K. larsenii
6. Ligules absent; leaves filiform, less than $0.5 \mathrm{~cm}$ broad. 7

7. Leaves up to $14 \mathrm{~cm}$; anther-crest not divided or crenate K. fallax

7. Leaves 15-20 cm long; anther-crest divided. K. filifolia

8. Petioles $\leq 1 \mathrm{~cm}$ long...................................... 9

8. Petioles $>2$ to $10 \mathrm{~cm}$ long 10

9. Ovary glabrous; leaf-blade green, glabrous on both surfaces with wavy margins

K. angustifolia

9. Ovary sparsely hairy; leaf-blade green with dark green spots above, pubescent on both surfaces with entire margin ...... K. maculifolia

10. Ovary glabrous; leaves glabrous on both surfaces with purple coloration at margins .... K. mahasarakhamensis

10. Ovary hairy; leaves pubescent below 11

11. Leaves tomentose on both surfaces; labellum pubescent K. koontermii

11. Leaves glabrous above, pubescent below; labellum glabrous 
12. Labellum shallowly divided or emarginate; staminodes oblong, 1-1.3 × c. $0.3 \mathrm{~cm}$ K. parviflora

12. Labellum divided to the base; staminodes broadly obovate or sub-orbicular, 1.5-2 × 1$1.7 \mathrm{~cm}$ K. elegans

13. Staminodes light brown or white 14

13. Staminodes lilac, purple or violet 21

14. Staminodes light brown K. saraburiensis

14. Staminodes white 15

15. Labellum purple K. marginata

15. Labellum white 16

16. Leaves dull green with dark blotches K. pardi

16. Leaves green without dark blotches 17

17. Labellum white with yellow spot at base .. 18

17. Labellum white with purple, lilac, or red .... 19

18. Leaves glabrous on both surfaces

K. roscoeana

18. Leave glabrous above and pubescent below .. K. koratensis

19. Calyx and ovary hairy; labellum white, sometimes with a darker reddish patch at the inner base of each lobe with longitudinal white line at the base of lobes K. phuphanensis

19. Calyx and ovary glabrous; labellum white with purple blotch at center or with purple marking at base 20

20. Bracts hairy K. laotica

20. Bracts glabrous K. galanga

21. Calyx and ovary hairy 22

21. Calyx and ovary glabrous 24

22. Stigma capitate, deep red purple; anther crest reniform; leaves glaucous, green ..... K. glauca

22. Stigma 2-lipped, creamy white or white; anther crest triangular or linear; leaves dark olivaceous black with grey markings above or black or black with light grey markings ... 23

23. Peduncles less than $1 \mathrm{~cm}$ long; stamens sessile; anther crest triangular and bend to the back; staminodes broadly obovate, light purple with white spot at base, longer than labellum; labellum light purple with pure white spot at base; leaves sessile, black or black with light grey markings, sparsely hairy above

K. nigrifolia

23. Peduncles c. $7.6 \mathrm{~cm}$ long; stamens with very short filament; anther crest very long linear apex entire rounded, recurved; staminodes obovate, mauve, as long as labellum; labellum lilac with the base pale yellowish-white spots; leaves petiolate, dark olivaceous black with grey markings above, glabrous above

K. pulchra

24. Calyx acute at apex K. picheansoonthonii

24. Calyx bifid at apex 25

25. Staminodes oblong, purple; labellum obovatecuneate, purple K. siamensis

25. Staminodes obovate, pink to light purple; labellum broadly obovate, pink to purple with two deep purple spots in the center

K. minuta

26. Leaves horizontal, near the ground............ 27

26. Leaves erect, pseudostem well developed ... 29

27. Leaves sparsely hairy above ..... K. lopburiensis

27. Leaves glabrous above 28

28. Staminodes broadly obovate, light purple; labellum light purple with deep purple at base K. udonensis

28. Staminodes oblong, white; labellum white with pale yellow spot at base, obovate. K. grandifolia

29. Leaves less than $5 \mathrm{~cm}$ wide ..... K. graminifolia 29. Leaves more than $5 \mathrm{~cm}$ wide 30 
30. Rhizome producing several shoots K. caespitosa

30. Rhizome producing a single shoot 31

31. Petioles more than $5 \mathrm{~cm}$ long 32

31. Petioles sessile to sub-sessile or up to $5 \mathrm{~cm}$ long 33

32. Labellum white to purple with deep purple at the center with prominent yellow patch from the base to sinus..... K. simaoensis

32. Labellum white to purple with deep purple at the center without yellow patch ... K. rotunda

33. Anthesis nocturnal, flower opens around 06 $\mathrm{pm}$ 34

33. Anthesis diurnal, flower opens around 05 ..... 35

34. Staminodes and labellum laid on the same plane; sinus depth two-third of labellum length; anther crest with irregular tridentate apex, the middle tooth shorter and wider than the outers K. albiflora

34. Staminodes upright with deflexed distal half of the labellum; sinus depth half of labellum length; anther crest with bilobed apex, usually with two small teeth between lobes. K. noctiflora

35. Leaves glabrous above K. aurora

35. Leaves scabrous or sparsely hairy above .... 36

36. Ovary glabrous; staminodes white to purple, broadly obovate to oblong, erect with deflexed distal half of the labellum; labellum deep purple toward the base, apically bilobed, lobes narrowly obovate, rounded at apex to slightly emarginated K. kamolwaniae

36. Ovary scabrous; staminodes light pink, broadly ovate, apex acute, laid on the same plane with labellum; labellum light pale pink with dark pink towards and almost reaching the base with white at base, respectively, deeply bilobed, each lobe obovate, apex rounded and slightly acute at tip K. takensis

\section{Acknowledgments}

Authors are grateful for the financial support from Mahasarakham University 2020 and the National Science and Technology Development Agency (FDA-CO-2563-11240-TH). We would like to thank Walai Rukhavej Botanical Research Institute, Mahasarakham University, Brio Garden, and our family for their facilities during this study and Dr. Jolyon Dodgson, UK for suggestions to improve the manuscript.

\section{Literature Cited}

BAKER J.G. 1890. Kaempferia L. In: HOOKER J.D. (ed.), The flora of British India. Volume 6. L. Reeve \& Co., London. pp. 218-224.

BOONMA T., SAENSOUK S. \& P. SAENSOUK 2020. Two new species of Kaempferia L. (Zingiberaceae) from Thailand. Taiwania 65(3): 371-381. https://doi.org/ 10.6165/tai.2020.65.371

HOLTTUM R.E. 1950. Zingiberaceae of the Malay Peninsula. Gardens Bulletin Singapore 13: 1-249.

INSISIENGMAY O., NEWMAN M.F. \& T.HAEVERMANS 2018. (2581) Proposal to conserve the name Kaempferia rotunda (Zingiberaceae) with a conserved type. Taxon 67(1): 207-208. https://doi.org/10.12705/671.19

JENJITTIKUL T. \& K. LARSEN 2020. Two new species of Kaempferia (Zingiberaceae) from Thailand. Natural History Bulletin of the Siam Society 64(1): 17-23. https:// doi.org/10.5852/ejt.2020.712

LARSEN K. \& S. SAKSUWAN LARSEN 2006. Gingers of Thailand. Queen Sirikit Botanic Garden, The Botanical Garden Organization, Chiang Mai.

RIDLEY H.N. 1899. The Scitamineae of the Malay Peninsula. Journal of the Straits Branch of the Royal Asiatic Society 32: 107.

SIRIRUGSA P. 1992. Taxonomy of the genus Kaempferia (Zingiberaceae) in Thailand. Thai Forest Bulletin (Botany) 19: 1-15. https://li01.tci-thaijo.org/index.php/ ThaiForestBulletin/article/view/25067 